\title{
Kreativitas dan Inovasi Dalam Pemasaran Untuk Mempertahankan dan Mengembangkan Kinerja Merek
}

\author{
H. Mochamad Edwar Romli \\ Dosen PNS Dpk L2 Dikti pada Universitas PGRI Palembang
}

\begin{abstract}
ABSTRAK
Artikel ini dimasudkan untuk memastikan bahwa kreativitas dan inovasi sangat diperlukan dalam pemasaran karena dengan adanya kreativitas dan inovasi, maka kinerja merek suatu produk dipertahankan dan dikembangkan. Mempertahankan kinerja merek melalui pemasaran dapat dilakukan melalui promosi-promosi yang dilakukan oleh organisasi bisnis terus-menerus dengan tujuan sekurangnya konsumen dapat mengetahui bahwa produk itu masih ada atau terus meningkat kinerja mereknya.
\end{abstract}

Kata kunci : Kreativitas, Inovasi, Kinerja

\section{A. PENDAHULUAN}

Suatu organisasi bisnis harus selalu melakukan pemasaran karena pemasaran merupakan ujung tombak usaha bisnis. Dengan pemasaran kita selalu mengingatkan konsumen akan produk yang kita hasilkan sehingga konsumen tidak lupa dengan produk kita tersebut,walapun produk kita itu sudah sangat terkenal. Apalagi bagi produk yang belum terkenal atau belum dikenal konsumen, maka tentu saja sangat membutuhkan pemasaran.Pemasaran yang diantaranya melalui promosi sangat dibutuhkan oleh suatu organisasi bisnis atau perusahaan supaya konsumen dapat selalu ingat dengan produk yang kita hasilkan.Konsumen dapat saja lupa dengan produk kita apalagi organisasi bisnis itu sudah lama sekali tidak melakukan promosi , dan banyaknya produk yang hampir sejenis.

\section{B. RUMUSAN MASALAH}

Sehubungan dengan uraian diatas, maka yang menjadi permasalahan dalam penulisan ini adalah:

1) Mengapa kreativitas dan inovasi diperlukan atau penting dalam pemasaran?

2) Bagaimana mempertahankan kinerja merek melalui pemasaran?

C. LANDASAN TEORI

1) Pengertian Pemasaran William J.Stanton dalam Daryanto (2011:75) mengatakan pemasaran adalah keseluruhan intern yang berhubungan dengan kegiatankegiatan usaha yang bertujuan untuk merencanakan, menentukan harga, mempromosikan, dan mendistribusikan harga dan jasa yang akan memuaskan kebutuhan pembeli baik pembeli yang ada maupun pembeli yang potensial. Sementara itu menurut Indriyo Gito Sudarmo (2012:14) pemasaran adalah suatu kegiatanyang mengusahakan agar produk yang diusahakannya itu dapat diterima dan disenangi oleh pasar.

Dari pengertian diatas dapat diketahui bahwa pemasaran itu ternyata mencakup kegiatan yang 
dimulai dari perencanaan produk, menentukan harga, menetukan cara promosi, dan saluran distribusi yang akan digunakan sehingga produk tersebut sampai kepada konsumendan dapat disenangi oleh konsumen.

Melalui pemasaran yang salah satu kegiatannya adalah promosi diharapkan dapat menggugah konsumen untuk menyenangi produk yang kita pasarkan, sehingga konsumen memperoleh kepuasan dan berkeinginan untuk membeli ulang atau menjadi pelanggan.

William J.Stanton

mengatakan pemasaran adalah kreasi dan realisasi sebuah standar hidup. Pengertian ini menjukkan kepada kita bahwa pemasaran itu tidak terlepas dari kreasi atau daya cipta dan realisasinya. Di dalam pemasaran itu sangat dibutuhkan kreativitas yang harus diwujudkan, sehingga pemasaran bukan lagi sebagai suatu gagasan belaka, tetapi sudah merupakan implementasi dari ide-ide yang ada. Temukan ide-ide yang menarik yang dapat menggugah konsumen

Pemasaran

memang menghendaki adanya ide-ide yang bagus atau menarik, kemudian dicoba untuk direalisasikan melalui promosipromosi yang dilakukan. Disini tentu saja sangat diperlukan kreativitas dan inovasi dari seorang manajer yang mampu menemukan ide-ide yang menarik yang dapat dijadikan sebagai materi promosi perusahaan atau organisasi bisnis kita.Ini memang tidak gampang karena membutuhkan perenungan kita.

Pendapat tentang pemasaran itu sangat banyak seperti diantaranya yang dikemukakan oleh Sofjan Assauri (2013:2) yang mengatakan pemasaran haruslah diarahkan pada konsumen yang ingin dituju sebagai sasaran pasarnya. Dari pendapat ini kita mengetahui bahwa sebelum kegiatan pemasaran itu dilakukan kita harus menentukan terlebih dahulu sasaran pasar yang ingin kita tuju. Setelah itu baru kita tentukan aktivitas pemasaran yang akan kita lakukan melalui kegiatan promosi yang gencar.

Dikemukakan pula oleh Sofjan Assauri (2013:3) pemasaran adalah hasil prestasi kerja kegiatan usaha yang berkaitan dengan mengalirnya barang dan jasa dari produsen sampai ke konsumen. Dari sini diketahui bahwa pemasaran itu merupakan suatu usahamengalirkan produk dari produsen ke konsumen,sehingga membuahkan hasil kerja berupa prestasi kerja. Di dalam pemasaran itu harus dilakukan upaya-upaya agar produk dapat diserahkan atau diterima oleh konsumen supaya dapat memberi keuntungan bagi perusahaan.

Usi Usmara (2008:1) mengatakan pemasaran merupakan upaya untuk menciptakan, membangkitkan dan memuaskan kebutuhan kebutuhan konsumen. Dari pendapat ini diketahui bahwa pemasaran itu merupakan upaya manajemen untuk menciptakan aktivitas - aktivitas pemasaran yang dapat menggugah/membangkitkan konsumen tertarik dengan produk yang dipromosikan oleh pihak manajemen. Melalui pemasaran yang dilakukan pihak manajemen berusaha membangkitkan kebutuhan konsumen supaya konsumen tertarik dengan produk yang kita promosikan itu sehingga konsumen punya keinginan untuk membeli dan memilikinya.

\section{2) Pengertian Kreativitas dan Inovasi \\ Conny Semiawan dalam Yuyus} Suryana dan Kartib Bayu (2013:204) mengartikan kreativitas sebagai kemampuan untuk menciptakan suatu produk baru, walaupun produk itu belum tentu benar-benar baru. 
Kreativitas ini masih dalam kaitannya dengan kemampuan, belum dalam wujud produk baru yang sudah ada, tetapi masih dalam bentuk ide yang ada dikepala kita.

Zimerer dalam Buchari Alma (2011:71) mengatakan kreativitas adalah kemampuan untuk mengembangkan ide mengembangkan ide baru dan menemukan cara baru dalam melihat peluang mapun problem yang dihadapi.

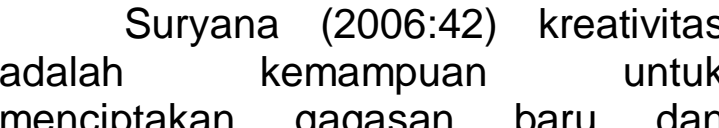
menemukan cara baru dalam melihat permasalahan dan peluang yang ada. Kreativitas itu berrkaitan dengan kemampuan menciptakan ide-ide atau gagasan. Kreativitas masih dalam bentuk ide, belum dalam bentuk produk yang riel. Tetapi bila kreativitas itu sudah diwujudkan menjadi produk, maka produk terserbut bisa disebut sebagai hasil inovasi. Dengan demikian inovasi dengan kreativitas itu sangat berhubungan erat. Inovasi merupakan kelanjutan dari kreativitas. Inovasi dihasilkan karena adanya kreativitas.

Inovasi itu dapat timbul karena adanya kreativitas. Inovasi dapat menyangkut banyak hal termasuk inovasi dalam berkomunikaasi, inovasi dalam layanan, inovasi produksi dan inovasi dalam produk dan proses produksi, dan sebagainya. Dengan adanya inovasi seperti yang telah dikemukakan diatas,akan mendorong konsumen lebih mudah dalam mengambil keputusan, dapat lebih banyak memiliki kesempatan dibidang financial, sehingga lebihdapat menghasilkan uang, dapat mmenjadi inceran/bidikan para investor untuk menanamkan uangnya dan memiliki kinerja financial yang lebih baik.

Oleh karena itu sangat penting dan kreativitas dan inovasi dalam pemasaran dilakukan supaya kinerja merek dapat lebih ditingkatkan lagi. Pemasaran diantaranya melalui promosi yang dilakukan harus selalu dilakukan supaya konsumen tidak lupa dengan produk kita, sehingga promosi disini berfungsi untuk selalu mengingatkan konsumen. Karena itu akan lebih baik bila ada kreativitas dan inovasi dari produk kita itu, yang dapat menunjukkan adanya perubahanperubahan dari produk-produk kita kearah yang lebih baik atau lebih maju yang menujukkan kinerja merek produk kita itu menjadi lebih berkualitas, variatif dengan berbagai macam produk walaupun dalam satu merek yang sama. Ini banyak terjadi pada produk sabun mandi, pasta gigi, supermie atau mie instant, kosmetik, dan sebagainya. Dengan cara seperti ini sebenarnya kinerja merek dari produk-produk itu akan ada selalu dalam ingatan konsumen.

Perubahan itu tidak harus selalu dalam bentuk perubahan produk. Tidak harus selalu produknya yang berubah, tetapi perubahan tersebut sesungguhnya bisa saja dalam kemasannya bahan baku pembentuk produk tersebut, cara mengomunikasikannya dengan konsumen atau cara promosi yang kita lakukan. Dengan pemasaran yang diantaranya melalui promosi-promosi yang kontinyu, maka kinerja produk kita akan selalu ada dalam ingatan konsumen.

Menurut Eman Suherman (2008: 25) promosi merupakan kegiatan penting dalam pemasaran, yang merupakan proses penyampaian data dan informasi, manfaat serta keunggulan produ kepada khalayak atau masyarakat luas oleh petugas promosi agar menjadi kenyataan di lapangan dimana promosi itu dapat dilakukan dengan cara yaitu:

a. Periklanan (advertising). 


\section{b. Penjualan pribadi (Persdonnel selling). \\ c. Promosi penjualan (Sales promotion). \\ d. Publisitas. \\ e. Hubungan masyarakat (Public relation). \\ f. Kombinasi (Combination).}

Walaupun ada berbagai cara atau alat promosi yang dapat digunakan tetapi pilih cara promosi yang lebih dapat menyentuh atau menggugah kemauan/kebutuhan konsumen, tentu saja dengan biaya yang lebih efisien, namun dapat menjangkau lebih banyak konsumen. Bisa saja cara promosi itu digunakan dengan lebih variatif untuk menggugah daya tarik konsumen.

\section{3) Konsep Tentang Merek}

William J.Stanton (1989:369) mengatakan merek adalah nama, simbol atau desain khusus atau beberapa kombinasi unsur-unsur ini yang dirancang untuk membedakan produk atau jasa sebuah perusahaan dari produk saingannya.Sedangkan menurut American Marketing Association (AMA) dalam Fandy Tjiptono (2015:187) merek adalah tanda yang berupa gambar, nama, kata, huruf-huruf, kata-kata, angkaangka susunan warna atau kombinasi dari unsur-unsurtersebut yang memiliki daya pembeda dan digunakan dalam kegiatan perdagangan barang atau jasa.

Dari pengertian merek diatas dapat diketahui merek itu merupakan suatu nama dari merek dagang yang dapat membedakan merek suatu produk dari produk lainnya. Dengan merek itu kita dapat mengenal suatu produk yang dapat memedakannya dari produk lainnya yang sejenis, walapun produk itu mungkin hampir sama, tetapi jelas ada perbedaannya. Misalnya produk sesama pasta gigi, produk sesama sabun mandi, produk sesama kecap manis, produk sesama kosmetik. Dengan mengenal mereknya saja kita sudah tahu itu produk apajenisnya yang dapat membedakannya dari produk pesaingnya. Ini merupakan salah satu kegunaan dari merek yang dapat membedakannya dari produk lain yang hampir sama yang menjadi pesaingnya. Selanjutnya menurut William J.Stanton pentingnya merek adalah:

a. Membuat pembeli yakin akan kualitas barang yang dibelinya. Konsumen akan lebih yakin membeli produk yang produk itu telah memiliki merek dari pada produk yang tidak bermerek.

b. Merek itu dapat di iklankan. Produk yang bermerek ternyata dapat mengiklankan dirinya sendiri, misalnya itu produk sabun mandi Lux, Palmolive, dan sebagainya. Merek-merek ini terkenal juga karena kinerja mereknya yang sudah dikenal luas oleh konsumen. Mereka tetap menjaga kinerja mereknya sampai sekarang, walaupun selalu bertindak kreatif dan inovatif diantaranya kemasannya, promosi yang mereka lakukan serta kegunaannya sebagai sabun kecantikan.

c. Konsumen lebih mudah mengenali suatu produk yang bermerek.

d. Merek dapat menambah prestise/gengsi bagi pemakai merek tersebut. Misalnya merek mobil BMW, mobil denganm merek Audi, sepatu bermerek Aigner, baju batik dengan merek Danar Hadi, dan produk dengan merek lainnya yang kinerja mereknya sudah dikenal sangat baik.

Supaya suatu merek produk itudapat memasarkan produknya diantaranya melalui promosi, maka 
perusahaan yang menghasilkan produk tersebut harus melakukan kreativitas dan inovasi secara kontinyu atau terus menerus. Perusahaan tersebut melalui manajemennya harus memiliki banyak ide untuk menumbuhkan dan mempertahankan kinerja merek dari produk yang dihasilkannya. Inovasi disini tidak lain merupakan perwujudan dari ide yang adauntuk menjadikan ide tersebut sebagai suatu produk. Memang tidak selalu inovasi itu menghasilkan produk yang benar-benar baru, tetapi yang baru itu bisa saja kemasannya, kegunaan atau manfaatnya atau bahan baku dari produk tersebut. Namun ini semua sudah dapat menjaga, menumbuhkan dan mengembangkan kinerja merek tersebut. Oleh karena itu dapat dikatakan kinerja merek dapat dipasarkan melalui pemasaran diantaranya melalui promosi yang dilkakukan secara kontinyu dengan kreatif dan inovatif, sehingga produk kita selalu ada dalam ingatan konsumen dan konsumen tidak lupa dengan produk kita, walaupun banyak produk lain yang hampir mirip atau sama.

\section{4) Kreativitas, Inovasi dan Pemasaran.}

Sudah biasa bahwa kompetitor akan mengincar kita terutama bila perusahaan kita dengan produk yang dihasilkan dianggapnya sebagai pesaing mereka. Dengan segala daya upaya mereka berusaha untuk menyaingi kita diantaranya melalui kinerja merek produk yang kita hasilkan. Oleh karena itu mereka selalu berusahauntuk mengungguli yang lain diantaranya melalui kreativitas dan inovasi yang akan menghasilkan kinerja merek produk serta selalu berkomunikasi bisnis dengan konsumen.

\section{PEMBAHASAN}

1) Pentingnya kreativitas dan inovasi dalam pemasaran

Seperti sudah dikemukakan kreativitas itu merupakan ide-ide atau gagasan. Walau masih merupakan ideide, tetapi ide-ide ini sangat dibutuhkan bagi bertumbuhnya suatu produk baru sebagai suatu hasil inovasi. Produk baru itu tidak berarti harus benar-benar baru, tetapi sebenarnya bisa saja produk lama yang sedikit mengalami perubahan seperti bentuknya yang berubah, kemasan yang berubah, rasanya yang berubah, dan sebagainya. Tetapi inovasi ini sangat penting artinya terhadap kinerja merek, khususnya dalam kaitannya dengan kegiatan pemasaran yang dilakukan suatu organisasi bisnis atau perusahaan. Adanya kreativitas dan inovasi yang dilakukan suatu organisasi bisnis dapat menjadi suatu aktivitas pemasaran yang dilakukan melalui promosi-promosi yang menjadi bagian dari pemasaran. Inovasi merupakan kelanjutan dari kreativitas. Tanpa kreativitas maka tidak ada inovasi-inovasi yang dapat dihasilkan.

Dengan adanya inovasi akan menunjukkan kinerja merek suatu produk. Kinerja merek suatu produk ini perlu dipasarkan kepada konsumen melalui promosi-promosi yang dilakukan supaya konsumen mengetahui tentang merek produk tersebut, walupun inovasi itu mungkin hanya merubah kemasan produk saja, hanya merupakanprubahan variant saja dari produk lama atau hanya merupakan merupakan perubahan cara promosi saja atas produk tersebut yang sebenarnya diketahui hanya merupakan suatu produk lama yang cara promosinya saja yang diubah, bukan produknya yang berubah. Tetapi dalam ini dapat ditegaskan bahwa kinerja merek sangat perlu dilakukan secara terus-menerus. Kemudian 
dengan adanya kinerja merek itu sangat perlu dilakukan kegiatan pemasaran diantaranya melalui promopromosi dengan mengguinakan cara atau alat promosi yang ada. Kita sebagai organisasi bisnis jangan pernah lupa untu melakukan pemasaran supaya konsumen akan tetap ingat atau tidak pernah lupa dengan produk kita.

\section{2) Cara mengetahui mempertahankan kinerja merek melalui pemasaran \\ Merupakan suatu usaha} kreasi/daya cipta yang diikuti dengan realisasi, cara menentukan promosi yang dikuti dengan cara melakukan komunikasi dengan konsumen maupun konsumen potensial. Oleh karena itu atas dasar ini untuk mempertahankan dan mengembangkan kinerja merek suatu produk, maka organisasi bisnis harus melakukan kegiatan pemasaran secara terus-menerus karena kompetitor selalu mengincar kita sebagai leader dalam merek produk tersebut. Kompetitor itu tidak pernah berhenti menyerang selagi mereka masih mempunyai kekuatan untuk menyerang pesaing-pesaingnya. Oleh karena itu kita jangan lengah atau beri kesempatan kepada mereka uintuk menyerang melalui promosi-promosi yang kita lakukan atas dasar kinerja merek produk kita yang selalu kita ubah secara kreatif dan inovatif.

\section{E. KESIMPULAN DAN SARAN}

1) Kesimpulan

a. Kreativitas dan inovasi sangat diperlukan dalam pemasaran karena dengan adanya kreativitas dan inovasi maka kinerja merek suatu produk dipertahankan dan dikembangkan.

b. Mempertahankan kinerja merek melalui pemasaran dapat dilakukan melalui promosi-promosi yang dilakukan oleh organisasi bisnis terus-menerus dengan tujuan sekurangnya konsumen dapat mengetahui bahwa produk itu masih ada atau terus meningkat kinerja mereknya.

2) Saran

a. Organisasi bisnis harus terus melakukan pemasaran melalui promosi-promosi yang dilakukan terhadap kerja merek produknya, supaya konsumen selalu ingat dengan produk kita. Untuk ini lakukan terus kreativitas dan inovasi atas produk kita agar kinerja mereknya mereknya dapat meningkat atau mengalami perubahan yang lebih baik.

b. Organisasi bisnis atau perusahaan harus terus atau selalu memperbaiki kinerja merek produk yang dihasilkannya melalui kreativitas dan inovasi yang mereka lakukan, kemudian mengomunikasikannya secara bisnis melalui promosipromosi yang variatif kepada konsumen kita dan konsumen potensial.

\section{DAFTAR PUSTAKA}

Alma, Buchari. 2011. Kewirausahaan. Alfabeta : Bandung.

Assauri, Sofjan. 2013. Manajemen Pemasaran. Raja Grafindo : Jakarta.

Asmara, Usi. 2008. Pemikiran Kreatif Pemasaran. Asuma Books : Yogyakarta.

Daryanto, 2011. Manajemen Pemasaran. Dirgahayu Permai : Bandung. 
Gitosudarmo, Indriyo. 2012.

Manajemen Pemasaran. BPFE : Yogyakarta.

Stanton, William J.1988. Prinsip Pemasaran. Erlangga : Jakarta.

Suherman, Eman. 2008. Tjiptono, Fandy. 2015. Strategi Kewirausahaan. Alfabeta : Pemasaran. Andi : Yogyakarta.

Bandung.

Yuyus Suryana dan Kartib Bayu, 2013. Kewirausahaan. Kencana : Jakarta.

Salemba Empat : Jakarta. 